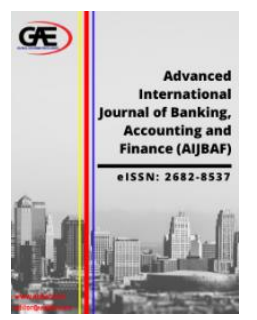

\author{
ADVANCED INTERNATIONAL JOURNAL OF \\ BANKING, ACCOUNTING AND FINANCE \\ (AIJBAF) \\ www.aijbaf.com
}

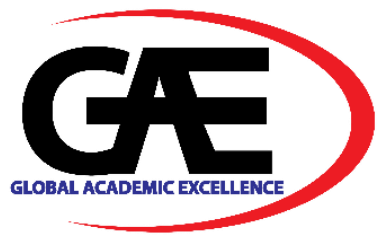

\title{
TRADE OPENNESS AND ECONOMIC GROWTH: CASE OF MALAYSIA
}

\author{
Khairunisah Kamsin ${ }^{1}$, James Alin ${ }^{2}$, Mori Kogid ${ }^{3}$ \\ 1 Faculty of Business, Economics and Accountancy, Universiti Malaysia Sabah, Kota Kinabalu, Malaysia. \\ Email: khairunisah1703@gmail.com \\ 2 Faculty of Business, Economics and Accountancy, Universiti Malaysia Sabah, Kota Kinabalu, Malaysia. \\ Email: maejames@ums.edu.my \\ 3 Faculty of Business, Economics and Accountancy, Universiti Malaysia Sabah, Kota Kinabalu, Malaysia. \\ Email: edy@ums.edu.my \\ Corresponding Author
}

\section{Article Info: \\ Article history: \\ Received date:26.08.2020 \\ Revised date: 13.09 .2020 \\ Accepted date: 14.09.2020 \\ Published date: 15.09.2020 \\ To cite this document:}

Kamsin, K., Alin, J., \& Kogid, M. (2020). Trade Opennes and Economic Growth: Case of Malaysia. Advanced International Journal of Banking, Accounting, and Finance, 2 (4), 4247.

DOI: 10.35631/AIJBAF.24004.

\begin{abstract}
:
This paper examines the role of foreign direct investment (FDI) and capital formation as mechanisms of trade openness for economic growth in Malaysia. This study found that foreign direct investment and capital formation are indicators of trade openness. Thus, this study proposes that policymakers should develop policies so that Malaysia could gain more benefits from trade openness and subsequently, accelerate the country's economic growth.
\end{abstract}

\section{Keywords:}

Trade Openness, Economic Growth, FDI, Capital Formation

\section{Introduction}

Over the past few decades, issues pertaining trade openness has garnered the interest of researchers. Trade openness, which denotes the sum of exports and imports of goods and services measured as a share of gross domestic product, has an important role to economic growth. In general, studies have found a positive link between foreign direct investment and capital formation, which subsequently, indicate the relationship between trade openness and economic growth. Economic growth is attributed to a range of factors including capital accumulation, labour, productivity growth and technology adaption (Beltramello, A et al, 
2011). As a developing, middle income country, Malaysia has practiced open trade since its independence and has become a prominent member of The Association of Southeast Asian Nation (ASEAN) since 1967. Trade openness in Malaysia increased from 37 per cent in 2016 to 39 per cent in 2017(World Development Indicator). In this regard, the economic growth of the top 5 ASEAN countries, including Malaysia is very sensitive to foreign direct investment (FDI), trade openness, import duty, and financial market telecommunication market liberalisation (Mohan R, 2007) Notably, as part of ASEAN, Malaysia has recorded second highest degree of trade openness compared to other members countries. Studies have found countries with the higher degree of trade openness are more open and recorded higher growth compared to countries with closed economy, (Edwards S. 1998) such as North Korea.

In many developing countries, FDI and capital formation are considered as the mechanisms to accelerate economic growth. Studies have shown the significant positive effect of FDI and capital formation on GDP growth (Adhikary B., K.,2011). Thus, FDI could create opportunities for investment, technology adaption, knowledge and development between other countries to increase productivity and subsequently, increase economic growth.

Capital formation also has a significant contribution to economic growth. In this light, capital formation positive capital investment by supplying additional capital to increase productivity in different sectors. This addresses issues pertaining the lack of initial stock of capital where capital formation tends to increase marginal rate of returns. Based on the discussion above, it is important to examine the linkage between foreign direct investment and capital formation and how this link could increase trade openness in Malaysia. Such examination is important as it helps policy makers understand the impact of FDI, capital formation and trade openness towards economic growth. In this study aims, related literature on the impact of trade openness to economic growth, foreign direct investment (FDI) and gross capital formation in Malaysia will be reviewed.

\section{Literature Review}

The current literature highlights that trade openness plays a significant role in accelerating economic growth in Malaysia. In this regard, past studies have examined relationship between trade openness and economic growth based on several indicators, including export, import, capital formation and foreign direct investment(FDI). This study reviews the previous studies on the role of capital formation and foreign direct investment (FDI) to avoid contradictory results. Previous research has shown a positive relationship between foreign direct investment (FDI) abd economic growth ( Adhikary B., K.,2011, Tahir M and Khan I ,2014.,P.,G,.S. Liargovas \& K.,S.,2012., Klasra M.,A,.2011) as well as the positive impact of capital formation the on economic growth. This is because it increases foreign capital investment in in countries the country and which could lead to higher productivity. Different studies have shown the significant impact of capital formation to economic growth including Yong A.,1995., Shahbaz, M.,2012., Khalid M. A and A.ali K,. H., 2017) . Thus, the next section reviews the literature on foreign direct investment (FDI) as the indicator of capital formation to examine the relationship between trade openness and economic growth.

\section{The relationship between Foreign Direct Investment (FDI) and Economic Growth}

Foreign direct investment (FDI) refers to the net inflows of investment, other than contributed by investors, to help an enterprise acquire a lasting management interest (10 percent or more 
of voting stock). It comprises of the amount of equity capital, reinvestment of earnings, other long-term capital, and short-term capital, as shown in the balance of payments. It is reflected in the net inflows (new investment inflows less disinvestment) from foreign investors and is divided by GDP (world bank indicator). In Malaysia, the third quarter of 2018 recorded the increase of FDI flow to MYR 3.95 billion, compared to a record low of MYR 2.84 billion in the previous quarter and MYR 11.74 billion in the previous year. Meanwhile in, 2017, foreign direct investment into the country amounted to MYR 41.04 billion which is a decrease from MYR 47.18 billion recorded in 2016. Foreign Direct Investment in Malaysia from 2008 until 2016 averaged at 13485.06 MYR Million, reaching an all-time high of 37325.00 MYR Million in the fourth quarter of 2011 while the record low of 2843.00 MYR Million was recorded in the second quarter of 2018 (MATRADE).

Tahir M and Khan I (2014) studied the impact of trade openness on economic growth and found that foreign direct investment (FDI) has a significant relationship with economic growth. The study is based on traditional growth model, the Solow Growth (1956). The finding of this study is in line with P., G,. S. Liargovas \& K., S. (2012). The study used the panel regression data from 1990-2008 to examine the role of trade openness in attracting foreign direct investment (FDI) and found that trade openness, in the long run, could benefit the inflow of foreign direct investment (FDI). Meanwhile, a study by Klasra M., A., (2011) used the autoregressive distribution lags model to analysis the data in period of time 19752004. The study provides evidence of a bi-directional causal relationship between short-term trade openness, foreign direct investment (FDI) and exports between Pakistan and Turkey.

A study by Rizuan A., R., et al (2018) focused on the determinants of economic growth in ASEAN countries by focusing on foreign. This study aims to examine the determinants of economic growth in ASEAN countries by looking for foreign domestic investment (FDI) in their study on the effects of foreign direct investment (FDI), trade openness and population on economic growth, domestic investment and examining the effects of foreign domestic investment, trade openness and population on economic growth. The study used the ARDL bound test approach for data analysis and found that foreign domestic investment has a positive relationship with economic growth in Malaysia, Thailand and Indonesia. In addition to population and trade openness, foreign domestic investments were also found to significantly affect economy growth in these countries. Another significant finding in Ridzuan A., R., et al (2018) is that foreign direct investment (FDI) has a positive relationship with economic growth in Malaysia, Thailand and Indonesia. Moreover, Mitra $\mathrm{P}$ and Khan G., S. (2014) also reported that FDI inflow has a statistically significant positive impact on economic growth in developing countries Adhikary B., K (2015) examined the linkage between FDI, trade openness, capital formation, human capital and economic growth rate. The study reported the importance of establishing a long-term balanced relationship among the variables and mentioned that FDI and trade openness have a positive effect on the economic growth rate in Nepal. The study also suggested that tariff and non-tariff barriers should be reduced in non-developed and developed countries to encourage FDI. The finding of this study is in-line Muhammad (2007) which found that foreign direct investment (FDI) encourages the process of technological diffusion and brings positive impact to economic growth. Based on the literature reviewed above, this present study focuses on examine the positive impact of foreign direct investment (FDI) on economic growth in Malaysia. 
Marelli and Signorelli (2011) analysed the economic growth and performance involving the integration of global economies in China and India. The study found that economic growth in both countries is accelerated by increasing their trade openness towards other countries in trade and FDI. A study by Adhikary (2011) in Bangladesh found that long-term trade openness has no contribution towards economic growth while FDI and capital formation has a positive impact to economic growth. Furthermore, the empirical research suggests that Bangladesh has increased the incentive in FDI and capital formation to gain more benefit to trade openness. Other than that, Liargovas and Skandalis (2012) investigated the importance of trade openness towards foreign direct investment inflow and found that FDI and trade openness have a significant and positive relationship on economic growth. This finding shows the importance of FDI as an economic strategy to sustain developing countries by establishing open trade with other countries.

Hermes and Lensink (2000) found that FDI influences economic growth when a country has a high human capital and financial development. Thus, the finding shows that the performance of human capital contributes to FDI and economic growth. Other than that, there is a significant, positive relationship between trade openness and FDI inflow. The relationship between both variables is influenced by exchange rate, inflation and the GDP per capita (Zaman et al 2018).

\section{Gross Capital Formation and Economic Growth}

Gross capital formation is also known as gross domestic investment. It consists of outlays on the addition of the fixed assets, as well the net changes in the inventories level world development indicator). According to Yong A (1995), the industrial sector adheres to rule pertaining the intersectional transfer of labour into the manufacturing sector. The study shows that relationship between both elements could have a positive impact and reflect the significance of these actors in different countries. Khalid M. A and A.ali K,.H (2017) explored the relationship between trade openness and long-term economic growth in China. The study used sample data from 1960-2015 and reported that the change in trade openness affects economic growth in the long run as through interaction with gross capital formation. This finding reflects the effect of trade openness on economic growth in the long run.

\section{Methodology}

This study will used time series data from the period of 1980-2018 by using ARDL bound test as a regression analysis. This study also will confirm the stationary of the time series data by using the unit root test before performing bound test. The purpose to used unit root test is because to determine the order of integration between time series data. If all variables were stationary, then it will fulfil the requirement to proceed to bound test.

\section{Propose Model}

Based on the critical review above this study propose the model as follow:

$$
\Delta(L G D P)_{i t}=\beta_{0}+\beta_{1} \Delta(L T O)_{i t}+\beta_{2}(L F D I)_{i(t-1)}+\beta_{3}(L C F)_{i(t-1)}+\varepsilon_{i t}
$$

The literature review explains that the relationship of trade openness and economic was supported by foreign direct investment and capital formation. the effect of FDI toward 
economic growth and capital formation toward economic growth shows relationship between both variables since FDI and $\mathrm{CF}$ as an engine to generate economic growth in this country.

\section{Conclusion}

Previous studies have shown that FDI and capital formation have significant impact economic growth and that FDI and capital formation have a significant positive impact on economic growth. The finding on the positive relationship between FDI and capital formation will lead to economic growth in Malaysia. Other than that, this study will also guide policy makers to form policies that could lead to more benefits from trade openness in Malaysia. The empirical and theoretical literature reviewed shown that trade openness significantly and positively affects the growth of economic activities, which subsequently increases productivity. This finding also indicates that trade liberalisation could positively accelerate economic growth in Malaysia. In addition, to achieve its aspiration to become a developed country, Malaysia should focus on human capital development to boost its economic growth.

\section{Reference}

Adhikary B., K (2015) Dynamic Effects of FDI, Trade Openness, Capital Formation, and Human Capital on the Economic Growth Rate in the Least Developed Economics: Evidence from Nepal. International journal of trade economic and Finance. Vol 6 No 1 .

Adhikary B., K.,2011) Impact of Trade Openness, FDI And Total Export On Economic Growth Of India: An Economteric Approach.Journal Of Economic And Finance. Volume 4. Issue 5 Pp 60-68

Beltramello, A., Backer, K. De, Mercader, V., \& Moussiegt, L. 2011. Opening Japan: Comparisons with Other G20 Countries and Lessons Learned from International Experience.

Foreign Direct Investment (FDI) data. Retrieved from http://www.matrade.gov.my/en

Khalid M. A and A.ali K,.H 2017. Investigation of The Relationship Between Trade Openness and Economic Growth In The Case Of China: International Journal of Research Granthaalayah Vol 5. (Iss.7)

Klasra M.,A. 2011. Foreign direct investment, trade openness and economic growth in Pakistan and Turkey: An investigation using bounds test: Institute of Management Sciences (IMS), Bahauddin Zakariya University, Multan, Pakistan 45:223-231

Marelli, E., \& Signorelli, M. 2011. China and India: Openness, trade and effects on economic growth. The European Journal of Comparative Economics, 8, 129-154.

Mitra P and Khan G., S. (2014) Impact of trade openness, FDI, inflow and total export on economic growth of India: An Econometric Approach. Journal of economics and Finance. Volume 4 Issue 5 PP 60- 68

Mohan R (2007) A Panel Data Analysis of Fdi, Trade Openness and Liberalization On Economic Growth Of The Asean -5. The Empirical Economics Letters, 6(1)

Muhammad (2007) "Foreign Direct Investment and Economic Growth: The Role of Domestic Financial Sector," Finance Working Papers 22205, East Asian Bureau of Economic Research.

Niels Hermes \& Robert Lensink(2003) Foreign Direct Investment, Financial Development and Economic Growth. The Journal of Development Studies, Vol 38, 2003 
Volume 2 Issue 4 (September 2020) PP. 42-47 DOI 10.35631/AIJBAF.24004

P.,G,.S. Liargovas \& K., S.,2012. Skandalis Foreign Direct Investment and Trade Openness: The Case of Developing Economies. Social Indicators Research, Vol. 106, No. 2 , pp. 323-331.

Qamar Uz Zaman, Zhang Donghui, Ghulam Yasin, Shah Zaman, Muhamad Imran (2018) Trade Openness and FDI Inflows: A Comparative Study of Asian Countries. European Online Journal of Natural and Social Sciences. Vol.7, No 2 Pp. 386-396

Ridzuan, A. R., Khalid, M. W., Zarin, N. I., Razak, M. I. M., Ridzuan, A. R., Ismail, I., \& Norizan, N. 2018. The Impact of Foreign Direct Investment, Domestic Investment, Trade Openness and Population on Economic Growth: Evidence from Asean-5 Countries. International Journal of Academic Research in Business and Social Sciences, 8(1), 128-143.

Shahbaz, M. 2012. Does Trade Openness Affect Long Run Growth? Cointegration, Causality and Forecast Error Variance Decomposition Tests for Pakistan. MPRA paper No 37391.

Tahir M and Khan, I 2014 "Trade openness and economic growth in the Asian region", Journal of Chinese Economic and Foreign Trade Studies, Vol. 7 Issue: 3, pp.136-152

Trade openness rate from 2016-2017 data. Retrieved from http:/data.worldbank.org/indicator

Young, A. 1995. The Tyranny of Numbers: Confronting the Statistical Realities of the East Asian Growth Experience. The quarterly Journal of Economics. Vol 110. No 3. PP. 641-680 